\title{
ADMINISTRAÇÃO E VALORES: em busca de novos caminhos para a compreensão do comportamento administrativo
}

\section{1- Marcos Luís Procópio*}

Doutor em Administração pela Universidade Federal de Lavras (UFLA), Brasil.

Professor Adjunto do Departamento de Administração da Universidade do Estado de Mato Grosso (UNEMAT), Campus de Sinop, Brasil.

marcos_procopio@yahoo.com.br

http://lattes.cnpq.br/9019463811795427 


\title{
ADMINISTRAÇÃO E VALORES: EM BUSCA DE NOVOS CAMINHOS PARA A COMPREENSÃO DO COMPORTAMENTO ADMINISTRATIVO
}

\section{RESUMO}

A integridade moral da Administração nunca foi tão questionada. Os constantes e evidentes "escândalos" corporativos que vêm marcando tanto a gestão de empresas privadas quanto a gestão pública nas últimas décadas por toda parte do mundo reforçam a idéia já difundida não apenas no senso comum, mas também na academia, de que a administração é uma atividade indiferente às questões éticas. O presente ensaio teórico tem por objetivo questionar a idéia de que a atividade administrativa é (ou se tornou nos dias de hoje) indiferente às questões éticas. O que se pretende fazer aqui, a partir de uma revisão de literatura, é um total contraponto a tal posicionamento, argumentando que embora a atividade administrativa possa de fato contribuir para a degradação social, ambiental e psicológico, nem por isso ela deixa de ser moralmente orientada. Adotando uma perspectiva epistemológica interpretativa ancorada no conceito ético de valor, entende-se aqui que existe uma orientação moral bastante visível por trás das praticas administrativas, muito embora essa possa não ser a orientação esperada por boa parte dos agentes que não ocupam posições gerenciais nas organizações. O texto é concluído com a constatação de que o estudo dos valores éticos constitui uma alternativa bastante promissora para a investigação, crítica e possível intervenção sobre o comportamento administrativo.

\section{Palavras-chave}

Administração, tomada de decisão, valores, ortodoxia, teoria crítica.

\section{MANAGEMENT AND VALUES: LOOKING FOR NEW WAYS TO UNDERSTAND THE ADMINISTRATIVE BEHAVIOR}

\begin{abstract}
Management's moral integrity has never been so questioned. The frequent and evident corporate "scandals" which have been staining both private and public management in recent decades throughout the world reinforce the idea that management activity is indifferent to ethical questioning, idea which is already widespread not only within common sense, but also within the academy. The present theoretical assay aims to question the idea that management activity is (or came to be nowadays) indifferent to ethical questioning. Through a literature review, this theoretical essay intends to do a total counterpoint to such position, arguing that although management activity can actually contribute to social, environmental and psychological damage, it's still morally guided. Adopting an interpretative epistemological perspective based on the ethical concept of value, it's understood here that there really is a clearly visible moral orientation behind management practices, although this may not be the orientation expected by most of those agents who do not occupy managerial positions within organizations. This theoretical essay concludes with the observation that the study of values is a very promising alternative to research, critique and possible intervention on administrative behavior.
\end{abstract}

\section{Keywords}

Management, decision-making, values, orthodoxy, critical theory. 


\section{Introdução}

A idéia segundo a qual a administração é uma atividade indiferente às questões éticas se faz claramente presente não apenas no discurso do senso comum, mas também no discurso acadêmico (Bartlett, 2003). A crescente sofisticação técnica do campo da Administração, associada à sua obsessiva preocupação com o ganho de produtividade material nas organizações, teriam levado os administradores ao abandono dos princípios éticos e, por conseguinte, à uma "crise" moral na gestão com consequências desastrosas em termos de degradação social, ambiental e psicológica (Enriquez, 1997). Especificamente no universo das empresas privadas capitalistas, "vêm-se argumentando que isso acontece porque os negócios são inerentemente não éticos em função da sua ênfase na busca por lucros" (Bartlett, 2003, p. 223)1. Os constantes e evidentes "escândalos" corporativos que vêm marcando tanto a gestão de empresas privadas quanto a gestão pública nas últimas décadas por toda parte do mundo² apenas reforçariam ainda mais essa acusação que, diga-se de passagem, não vem apenas de vozes externas ao campo, mas vem também de vozes internas (Hayibor \& Wasieleski, 2009). Segundo essas vozes, a gestão teria sofrido um "esvaziamento" ético que, por sua vez, seria o responsável por sua incapacidade de evitar e/ou solucionar os problemas psíquicos, sociais e ambientais causados em função do seu próprio avanço (Enriquez, 1997).

Certamente, o campo da Administração não é o único onde tais críticas se fazem presentes. A acusação de falta de ética atinge também outros campos como o da Política e o da Justiça e, com efeito, não poderia estar desvinculada de acusações mais amplas sobre a falta de ética na própria sociedade contemporânea de um modo geral. A idéia difundida de que a Administração é uma área indiferente às questões éticas encontra-se, desse modo, amparada na idéia de que a própria sociedade atual, no sentido amplo, é uma sociedade tecnicista que enfrenta uma "crise" de valores morais devido ao fato de as pessoas estarem cada vez mais desprovidas de sentido ético em suas ações (Eça de Almeida, 1989; Enriquez, 1997).

O presente ensaio teórico tem por objetivo questionar a idéia de que a atividade administrativa é (ou se tornou nos dias de hoje) indiferente às questões éticas. Sem partir para nenhuma espécie de defesa da área e/ou de sua forma de atuação, o que se pretende fazer aqui, a partir de uma revisão de literatura, é um total contraponto a tal posicionamento argumentando que, embora a atividade administrativa tenha se sofisticado tecnicamente e embora ela possa de fato contribuir ativamente para a degradação social, ambiental e psicológico, nem por isso ela deixou ou deixa de ser eticamente orientada. Ao contrário, será argumentado que é justamente o fato de a atividade administrativa estar embasada em valores morais específicos que dá a ela a legitimidade e, por conseguinte, a força necessária para causar tais danos.

A partir da adoção de uma perspectiva epistemológica interpretativa, entende-se no presente estudo que há realmente uma orientação ética ou moral ${ }^{3}$ bastante visível por trás das praticas administrativas, muito embora essa possa não ser a orientação esperada por boa parte dos agentes que não ocupam posições gerenciais dentro das organizações. Ademais, entende-se aqui que a Administração, para que possa efetivamente contribuir para a retomada do bem-estar social de forma geral, deve imediatamente questionar os valores éticos que orientam a tomada de decisão gerencial. Obviamente, esse questionamento exige, em primeiro lugar, que a Administração seja capaz de reconhecer a natureza ética de tal atividade; e isso implica, sem sombra de dúvidas, um profundo questionamento da sua aparente amoralidade.

O presente ensaio teórico se justifica, então, pelo esforço realizado no sentido de revelar que além de não ser uma atividade moralmente indiferente, a tomada de decisão administrativa pode ser questionada e, quiçá, até mesmo "renovada" através da autêntica discussão de seus reais valores morais orientadores. Tais valores, por sua vez, são desprezados tanto por autores que, por pertencerem à ortodoxia dos estudos em Administração, prescrevem que a tomada de decisão gerencial deve ser uma atividade fundamentalmente técnica e moralmente neutra, quanto por autores críticos que, ao entenderem que a gestão se tornou uma atividade "racional-instrumental" meramente mecânica ou compulsiva, não são capazes de reconhecer nela qualquer moralidade.

Para atingir seu objetivo, o presente ensaio teórico se encontra estruturado em três seções além desta introdução e da última que contém suas considerações finais. A primeira seção tem como propósito discutir a ação administrativa em sua completude, procurando demonstrar que, na qualidade de uma deliberação humana, tal ação necessariamente traz consigo uma orientação moral irredutível. Na segunda e na terceira seções serão identificadas as vozes que, tanto oriundas da ortodoxia do pensamento administrativo quanto oriundas da teoria crítica, respectivamente, ajudam a conservar a idéia de que a 
tomada de decisão administrativa é uma atividade moralmente "indiferente" ou "vazia" e que, por isso, é tão nociva à sociedade, ao homem e ao meio-ambiente. A título de considerações finais, serão identificadas as fragilidades de ambos os argumentos (ortodoxo e crítico) com o intuito de se demonstrar que em nenhum dos dois há uma efetiva disposição para reconhecer que o comportamento administrativo, muito embora possa ter se sofisticado tecnicamente e muito embora possa realmente ser danoso para o indivíduo, sociedade e meio-ambiente, nem por isso deixou de ser moralmente orientado.

\section{Administração, Valores e Moralidade}

A tomada de decisão humana, enquanto baseada em um julgamento minimamente reflexivo, é um ação social significativa na qual diferentes dimensões da realidade vivida pelo agente decisor (dimensão factual, moral, estética e religiosa) são por ele consideradas de um modo intrincado. Salvo em casos de absoluta determinação externa (coerção) ou em casos de puro impulso interior (compulsão), as decisões e ações humanas são resultados de uma avaliação ou julgamento minimamente consciente acerca da realidade (material e simbólica) que cerca o agente social. Essa realidade, por sua vez, não se torna apreensível para o agente a não ser através da mediação dos valores.

Grosso modo, valor tem a ver com tudo o que é importante em termos de conduta e tomada de decisão humana. São os valores que permitem ao agente decisor identificar, dentre um sem-número de coisas, ações e eventos, aquilo que de algum modo importa e que, portanto, tem algum significado para o desenvolvimento da sua ação. Segundo Álvaro Tamayo (1998, p. 57),

a palavra valor diz respeito à oposição que o ser humano estabelece entre o principal e o secundário, entre o essencial e o acidental, entre o desejável e o indesejável, entre o significante e o insignificante. Ela expressa a ausência de igualdade entre as coisas, os fatos, os fenômenos ou as idéias. Dessa forma, aplica-se o termo valor em todas aquelas circunstâncias em que uma delas é julgada superior a outra, em que uma delas é objeto de preferência. O valor implica, portanto, no rompimento da indiferença do sujeito diante dos objetos, do comportamento, dos eventos ou das idéias.

Tal como complementa Simon Blackburn (1997, p. 399),

reconhecer um certo aspecto das coisas como um valor consiste em levá-lo em conta na tomada de decisão ou, em outras palavras, em estar inclinado a usá-lo como um elemento a ser considerado na escolha e na orientação que damos a nós próprios e aos outros.

Assim, toda vez que algo desperta a atenção de um agente social no curso de uma ação qualquer e passa, então, a influenciar suas escolhas, esse algo se relaciona a algum valor.

Os julgamentos de valor estão presentes em todo tipo de ação e decisão humana significativa, e não se limitam apenas a sua dimensão moral, o popularmente conhecido "juízo de valor". Tal como observou John Dewey (1964, p. 111),

julgamentos morais, sejam o que forem mais, são uma espécie de julgamento de valor. [ ...] julgamentos de valor não se limitam a questões explicitamente morais em seu significado. Ao considerarmos poemas, quadros e paisagens, do ponto de vista de sua qualidade estética, o julgamento refere-se a valores. Avaliam-se os homens de negócio quanto a sua posição econômica, ao darem crédito, etc. Não nos contentamos com declarações puramente externas sobre o tempo, porquanto é ele medido pelo termômetro e pelo barômetro. Designamo-lo bom ou desagradável: epítetos de valor. Artigos de mobiliário são julgados úteis, confortáveis ou o contrário disso. [...] Quando pronunciamos o julgamento 'bem' ou 'mal', calculamos em termos de valores. Quando julgamos declarações de outros, sejam feitas em conversação casual ou em discursos científicos, e nos pronunciamos serem 'verdadeiras' ou 'falsas', estamos fazendo julgamentos de valor. De fato, o principal embaraço em dar exemplos dos julgamentos de valor está em vermo-nos, constantemente, empenhados em fazê-los.

Como reforça o mesmo autor, mais adiante na mesma obra, "a deliberação moral difere de outras formas, não como processo de formar julgamento e de chegar ao conhecimento, mas na espécie de valor sobre o qual se cogita" (Dewey, 1964, p. 121).

Os valores, que podem ser tanto factuais quanto morais (ou ainda estéticos ou religiosos), operam, então, como mediadores da realidade para o tomador de decisão. Nunca são "finais" por si mesmos, mas sim são sempre "meios" heurísticos para interpretação e ação sobre a realidade (Dewey, 1964). Com efeito, os valores não são nem meios nem fins das ações, mas, na qualidade de instrumentos heurísticos, "iluminam" tanto os meios quanto os fins em questão ${ }^{4}$. 
Segundo Shalom Schwartz e Wolfgang Bilsky (1987, p. 551), valores são: “[ ...] (a) conceitos ou crenças, (b) sobre fins desejáveis ou sobre comportamentos, (c) que transcendem situações específicas, (b) guiam a seleção ou avaliação de comportamentos e eventos, e (d) são ordenados por sua importância relativa". Além disso, os autores acrescentam que (e) os valores não são inerentes as próprias coisas e ações avaliadas, mas sim, constituem as referências, princípios ou critérios a partir das quais tais "objetos"

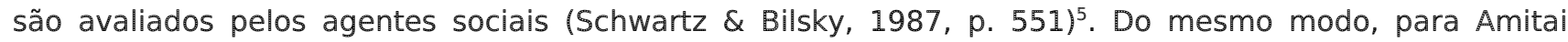
Etzioni (1988) os valores são "critérios" a partir dos quais as decisões humanas são tomadas. Como complementa Elizabeth Ravlin (2003, p. 1402), “os valores agem como um dispositivo de análise de percepções que influencia o que vemos em nosso ambiente, e como um canal para influenciar as decisões comportamentais".

A tomada de decisão humana é um todo indivisível. Segundo Cris Provis (2010), ela é normalmente baseada em um único julgamento, muitas vezes provocado de modo intuitivo e emotivo, que congrega em si as duas dimensões valorativas aqui apresentadas. Por isso, não faz sentido algum falar sobre uma decisão moral e uma outra factual como se ambas fossem independentes. O que é possível fazer, apenas para efeito de análise e argumentação, é separar as duas dimensões da tomada de decisão sem perder de vista sua complexidade. Assim, o que diferencia a dimensão moral da tomada de decisão da sua dimensão factual é justamente o emprego de critérios de julgamento normativo-afetivos de caráter moral por parte do agente decisor, relacionados ao que é "bom" ou "ruim", "melhor" ou "pior", ao invés do simples emprego de critérios de julgamentos meramente normativos, exclusivamente relacionados ao que é suficiente ou insuficiente em termos factuais.

É muito importante reforçar, frente as definições de valor ora apresentadas, que os valores factuais não equivalem diretamente aos fatos materiais, assim como valores éticos não equivalem diretamente à realidade moral da tomada de decisão. Ambos são recursos interpretativos, presentes no "eu" do agente decisor, respectivamente capazes de dar significado tanto à parcela factual quanto à parcela moral da mesma realidade relevante para efeito de escolha e orientação da ação. Assim, nem as condições factuais nem as condições morais implicadas em uma decisão podem existir para o agente decisor sem a mediação oferecida pelos seus respectivos valores. Do mesmo modo, não são todos os fatos nem todos os "bens" que são considerados pelo agente decisor no curso da sua ação, mas apenas aqueles que podem ser identificados através dos seus respectivos valores. Afinal, “os valores [...] agem não apenas como respostas avaliativas, mas sim como uma estrutura organizada primária para grande parte de nosso sistema de crenças mais gerais, inclusive as cognições comumente percebidas como 'fatos'" (Ravlin, 2003, p. 1401).

Os valores, embora sejam utilizados pelo indivíduo como critérios para interpretação subjetiva da realidade e consequente tomada de decisão, são intersubjetivos e pertencem ao contexto social no qual tal agente foi socializado (Dewey \& Tufts, 2008; Etzioni, 1988). Por isso, os valores que orientam as decisões e ações humanas nunca são "invenções" subjetivas e idiossincráticas, particulares para cada indivíduo. Ao contrário,

os valores são adquiridos de instituições pertencentes à sociedade (família, sistemas econômicos e políticos) e de seu contexto cultural. No início [ da vida do indivíduo] são adquiridos isoladamente, de forma absoluta. À medida que o indivíduo amadurece, ele os integra em um sistema hierárquico [ ...], em níveis de prioridade (Ravlin, 2003, p. 1401).

Da mesma forma, os valores não são inatos, herdados geneticamente ou programados biologicamente, mas são parte da cultura. Desse modo, percebe-se que valores são convenções sociais que podem ser transmitidas, ensinadas e aprendidas pelos membros de uma sociedade. Adicionalmente, na qualidade de convenções sociais úteis à avaliação e orientação das decisões e ação humanas, os valores podem ser expressos e comunicados através de proposições, assertivas ou, mais simplesmente, afirmações sobre tudo aquilo que está envolvido na tomada de decisão. Todavia, a reprodução dos valores em uma cultura não ocorre de modo automático ou mecânico, sem a participação ativa do sujeito. Com efeito, ao tomar uma decisão segundo um valor qualquer, o indivíduo está reforçando, a partir da ação que emana da sua avaliação subjetiva, a importância social do valor em questão.

Em uma sociedade moderna, caracterizada pela existência de um sem-número de diferentes grupos sociais e instituições, há inúmeros valores em uso. Poucos valores são efetivamente universais e aqueles que orientam as decisões e ação cotidianas são tão diversos quanto os grupos e instituições existentes na sociedade. Valores específicos guiam decisões e ações específicas em instituições ou grupos sociais 
igualmente específicos; e isso se aplica tanto aos valores factuais quanto aos valores morais. Assim, diferentes valores se encontram distribuídos por diferentes grupos sociais (família, religião, trabalho, comunidade) segundo as especificidades de cada um dos grupos e de sua história. Desse modo, existem os valores laborais (Porto \& Tamayo, 2007) que pertencem as pessoas que compõem um grupo ou classe profissional específica, por exemplo, a classe das enfermeiras (Perocca, 1997); os valores organizacionais (Tamayo \& Gondim, 1996) que pertencem aos integrantes de uma organização ou tipo de organização específica (empresa pública, privada, etc.) e os valores sociais "gerais" (Porto \& Tamayo, 2007) que guiam as ações e decisões das pessoas nas esferas mais amplas da sua vida social, como o valor da cidadania. Por isso, se o que se deseja é entender os valores que orientam a tomada de decisão administrativa, faz-se necessário reconhecer o caráter institucional do campo da Administração, sua história e os hábitos e padrões de comportamento que os administradores costumam seguir ao agir. Isso significa pensar a Administração como um campo (Bourdieu, 2001), uma instituição (Berger e Luckmann, 1985) ou um costume (Dewey, n.d.).

Uma análise dessa natureza que, diga-se de passagem, não cabe no presente ensaio teórico, precisaria levar em conta as diversas subdivisões do campo da Administração (administração pública, de empresas privadas, de organizações do terceiro setor) e, além disso, o nível de autoridade e responsabilidade do agente decisor em questão dentro das organizações que compõem essas subdivisões: alta administração, administração média, supervisão imediata. Não obstante, precisaria ainda levar em conta o contexto social, econômico, político e cultural dentro do qual a decisão administrativa em questão ganha corpo. Por ora, basta reconhecer que o campo a Administração, com sua Ciência, sua prática, seus mitos, rituais e hábitos diversos (prever, organizar, comandar, coordenar, controlar) oferece aos agentes sociais nele inseridos um conjunto de valores próprios e específicos que não necessariamente coincidem com os valores existentes em outros campos ou instituições e que podem, inclusive, entrar em choque com aqueles ${ }^{6}$.

O administrador toma conhecimento da parcela factual da realidade implicada na sua decisão através de convenções, padrões, conceitos ou critérios quantitativos que fornecem a ele noções, por exemplo, de peso, volume, tempo de atravessamento, custo, consumo de energia, etc.. Estas convenções, padrões, conceitos ou critérios quantitativos, de natureza “lógico-empírica" (Etzioni, 1988), são os valores factuais empregados na interpretação da realidade empírica da tomada de decisão administrativa e estão em "sintonia" com o contexto específico dentro do qual delibera o administrador. Exemplos genéricos desses valores são: o sistema de pesos e medidas, as convenções operacionais que por ventura normatizam tecnicamente uma operação e o próprio dinheiro que fornece a referência econômicofinanceira para as decisões administrativas ${ }^{7}$. Já no que diz respeito ao conhecimento da parcela moral da realidade implicada na sua decisão, o administrador se utiliza de convenções, padrões, princípios ou referências morais, os chamados valores éticos ou morais. Estes valores, por sua vez, são de natureza "normativo-afetiva" (Etzioni, 1988) e permitem ao administrador julgar qualitativamente se uma decisão é "boa" ou "ruim", "correta" ou "incorreta", "aprovável" ou "reprovável" sob o ponto de vista moral. Assim como ocorre com os valores factuais, seu uso também é contextualizado e por isso eles não podem ser corretamente compreendidos fora desse contexto. Nesse sentido, Alex Coltro e Silvio Aparecido dos Santos (1998, p. 07) reforçam que "diferentes formações sociais e culturais instituíram conjuntos distintos de valores éticos enquanto fomentadores de padrões de conduta, de relações intersubjetivas e interpessoais, e de comportamentos sociais [...]" que se tronaram relativamente específicos e diferenciados na sociedade. Por isso, "o comportamento na esfera moral varia de acordo com o tempo e o lugar; varia também conforme as exigências das condições nas quais os homens se organizam para estabelecerem as formas efetivas e práticas do trabalho" (Coltro \& Aparecido dos Santos, 1998, p. 08). Isso explica porque “as pessoas como gestores profissionais no âmbito da organização possuem um 'ethos' específico, diverso do mundo-da-vida humana em geral" (Coltro \& Aparecido dos Santos, 1998, p. 08). Exemplos genéricos de valores morais presentes no campo da Administração são: a honestidade, a transparência, a satisfação das necessidades do cliente ou usuário, o bem-estar do trabalhador, o zelo pelas normas e regras que regem o trabalho, o sucesso na consecução de metas predefinidas e a responsabilidade econômica, social, ambiental e/ou psicológica pelas consequências das decisões tomadas.

Muito embora o julgamento da realidade e a tomada de decisão concreta congreguem tanto valores éticos quanto valores factuais, esses dois valores não possuem o mesmo grau de importância heurístico como referências orientadoras das escolhas humanas; e isso certamente se aplica às escolhas do administrador. Isso ocorre porque os valores são hierárquicos por natureza, tanto dentro da sua própria 
dimensão cognitiva (nesse caso, factual ou moral) quanto entre essas dimensões (Ravlin, 2003; Tamayo, 1998; Etzioni, 1988; Dewey, 1964).

Uma vez que os valores éticos são capazes de qualificar a intencionalidade presente em toda ação verdadeiramente humana, enquanto os valores factuais são apenas capazes de quantificar os elementos empíricos nela envolvidos, os primeiros são mais "determinantes" do que os segundos no que diz respeito ao seu poder de orientar a tomada de decisão. Afinal, argumenta John Dewey (2008a), os julgamentos de qualidade sempre antecedem os julgamentos de quantidade e "a deliberação moral não trata da quantidade [ ...], mas da qualidade" (Dewey, 1964, p. 121). Por isso, ao decidir e agir, a pessoa não apenas avalia os elementos empíricos percebidos na sua realidade decisória, mas avalia prioritariamente os elementos morais percebidos nas ações das outras pessoas com as quais interage, ações essas que, por sua vez, também fazem parte do todo complexo que é sua realidade decisória. Esse argumento é plenamente corroborado por Amitai Etzioni que, ao esboçar sua teoria da tomada de decisão moral em seu livro The moral dimension (1988), faz a distinção entre a importância dos critérios normativo-afetivos, de natureza moral, e a importância dos critérios lógico-empíricos, de natureza factual, para efeito de condução das escolhas humanas. De acordo com Etzioni (1988, p. 112), "grande parte das escolhas feitas por indivíduos são feitas em terreno normativo-afetivo e não em terreno lógico-empírico [ ...]". Assim,

[...] os fatores normativo-afetivos modelam significativamente a informação que é obtida, os modos como é processada, as inferências que são feitas, as opiniões que são consideradas e as opinióes que são finalmente escolhidas. Isto é, em uma extensão considerável, cognição, inferência e julgamento - assim como a tomada de decisão - não são empreendimentos lógico-empíricos, mas são sim governados por fatores normativo-afetivos [ Em uma palavra:] "os fatores normativo-afetivos provêem, então, o contexto dentro do qual as considerações lógico-empíricas são empregadas" (Etzioni, 1988, p. 94).

$\mathrm{Na}$ prática, construção de instalações e edificações, operações logísticas, produção de bens e serviços, tudo isso implica decisões administrativas amplamente baseadas em valores factuais. Para que possam ser devidamente ponderados na tomada de decisão, ou seja, para que possam ser operacionalizados, os fatos e dados existentes no mundo material precisam ser mensurados de alguma forma: eis a inquestionável importância dos valores factuais. Por outro lado, essas mesmas decisões, embora tenham seus elementos empíricos aferidos pelos valores factuais, contêm intenções (coisas que não pertencem ao mundo do "empírico") e, por isso, são em última instância orientadas por valores morais. Como já havia reconhecido Herbert Simon (1979, p. 48),

as decisões são algo mais do que simples proposições factuais. Para ser mais preciso, elas [também] são descrições de um futuro estado de coisas, [...] elas possuem, também, uma qualidade imperativa, pois selecionam um estado de coisas futuro em detrimento de outro e orientam o comportamento rumo à alternativa escolhida. Em suma, elas [ as decisões] possuem ao mesmo tempo um conteúdo ético e um conteúdo factual.

Pode-se seguramente afirmar, com base na leitura de Simon (1979), que são muitos raros os casos onde as decisões administrativas não envolvem questões éticas, além das factuais. Tal como afirma o autor, "parece bem claro [ ...] que a maior parte das proposições éticas vêm misturadas com elementos factuais" e vice-versa (Simon, 1979, p. 52). Na verdade, Simon (1979) é bastante enfático ao argumentar que não há como separar terminantemente as questões éticas das questões factuais na tomada de decisão administrativa: "na prática, a separação dos elementos éticos e factuais [ ...] só pode ser efetuada até certo ponto" (Simon, 1979, p. 55). Mais do que isso, como reconhece o próprio Simon (1979), a presença explícita e direta de moralidade nos fins pretendidos pelos administradores (ex.: prestar um "bom" atendimento ao cliente, zelar pelo "bem-estar" do funcionário, ampliar o "bem-estar" do cidadão, fabricar um "bom" produto, fazer "bom" uso dos recursos organizacionais) não é condição necessária para que os julgamentos éticos se façam presentes na tomada de decisão administrativa. Os valores éticos estão sempre presentes na tomada de decisão, mesmo que implicitamente, na medida em que a ação administrativa também pode partir de premissas éticas preexistentes ou anteriores à própria avaliação dos dados e fatos empíricos. Simon (1979, p. 82) reconhece a existência de tais premissas decisórias ao afirmar que "a escolha individual ocorre num ambiente de pressupostos - premissas que são aceitas pelo indivíduo como bases para sua escolha - e o comportamento é flexível apenas dentro dos limites fixados por esses pressupostos". Dito de outro modo, as proposições éticas, quando não explicitadas nos objetivos previamente intentados pelos administradores, constituem o "pano de fundo" de qualquer decisão administrativa justamente porque decisões administrativas, enquanto ações humanas e sociais, não se processam em um vácuo moral. 
Assim, ao projetar um edifício, um produto industrial ou um sistema de distribuição logístico, o administrador está também projetando tais coisas moralmente. Avalia moralmente o empreendimento, além de fazê-lo factualmente, mesmo que essa avaliação moral seja eminentemente pautada no valor egoísta do "sucesso profissional", valor esse que, por sua vez, indicará se ela se trata de uma "boa" escolha para a própria carreira do administrador acima de qualquer outro impacto sobre a vida de qualquer outro nela envolvido. Ao decidir, o administrador não leva em conta apenas os dados e fatos concretos que condicionam empiricamente suas decisões. Leva em conta, em primeiro lugar, o peso ou carga moral das suas decisões, ou seja, leva em conta o quão "bom" ou "ruim", “justo" ou "injusto", "correto" ou "incorreto" serão seus resultados para alguém, mesmo que esse "alguém" seja ele próprio. Por isso, ele está sempre lidando com valores éticos além dos factuais. Seu julgamento moral se encontra sobreposto ao seu julgamento factual, formando um todo intrincado. Tal como reconhece Simon (1979), em concordância com Etzioni (1988), não há apenas uma indissociabilidade entre julgamentos éticos e julgamentos factuais na tomada de decisão administrativa como há também uma relação de dependência dos segundos para com os primeiros.

A moralidade é, por certo, algo irredutível em se tratando de decisões e ações humanas, dentre as quais se encontram as decisões e ações administrativas. Como Dewey (2008b, p. 193) já havia observado ainda antes de Simon (1979) e Etzioni (1988), "o comportamento humano parece ser influenciado, se não controlado, por considerações com as expressas nas palavras 'bom-ruim', 'certo-errado', 'admirávelhorrível', etc.. Toda conduta que não é simplesmente impulso cego nem rotina mecânica parece envolver valoração" moral. Por isso, como sustenta Etzioni (1988, p. 138), "nós não podemos escapar da tarefa de julgar fins, não em termos simples de dar-lhes pontos de mérito ou demérito baseados nas nossas preferências e valores individuais, mas em termos de uma ética cujo critério pode ser justificado [ ...]".

A impossibilidade de se reduzir o elemento moral da realidade ao elemento factual da mesma realidade complexa na ocasião da tomada de decisão administrativa, constatada na discussão precedente, é incompatível com a opinião de que a conduta gerencial é moralmente indiferente ou "neutra" por se tratar meramente de uma questão técnica. Ao contrário, reconhecer a existência dessa irredutibilidade implica reconhecer que a atividade administrativa é, acima de tudo, moralmente orientada a despeito da inquestionável importância da sua dimensão factual. Então, como será debatido na próxima seção, a existência dessa irredutibilidade não é sustentada nem por aqueles autores prescritivos que, ao proporem uma teoria da decisão, optam por excluir todos os elementos morais envolvidos nas escolhas do administrador, nem por aqueles autores analíticos que, ao refletirem sobre a tomada de decisão administrativa, atribuem a ela um caráter demasiadamente mecanomórfico ou compulsivo, caráter esse que, por sua vez, se fosse realmente constatado na prática organizacional, impediria por completo a atividade administrativa de ser moralmente orientada.

\section{A Fragmentação Teórica da Tomada de Decisão e a Contribuição de Herbert Simon para a Mitigação da Moralidade na Administração}

Se o entendimento de que a atividade administrativa é eticamente insensível se difundiu não apenas no senso comum, mas também na academia, isso se deu à confluência de várias vozes, tanto de dentro como de forma do campo da Administração. No presente ensaio teórico foram identificadas três dessas vozes, a saber: (1) a própria noção tecnicista, operacionalista e neutralista de tomada de decisão administrativa, presente na teoria administrativa ortodoxa e sistematicamente concebida por ela para permitir que o tomador de decisão possa legitimamente ignorar a dimensão moral da realidade gerencial; (2) parte da chamada "teoria crítica" da Administração e dos Estudos Organizacionais que, ao associar o comportamento administrativo a uma concepção de racionalidade instrumental estreita e mecanomórfica, acaba também por ignorar a existência da moralidade nas decisões e ações administrativas e se torna, assim, incapaz de criticá-la; e, finalmente, (3) vozes externas ao campo da Administração que reforçam a idéia de que a sociedade contemporânea é uma sociedade demasiadamente tecnicista, esvaziada de valores morais capazes de "humanizar" as relações sociais, e que, portanto, legitima uma gestão moralmente insensível. Nesta seção e na próxima serão analisadas as vozes da ortodoxia e da teoria crítica, respectivamente. Quanto às vozes externas, certamente determinantes para a sustentação da Administração e de seu modo tecnicista de agir na sociedade atual, algumas colocações serão agregadas aos debates, porém uma atenção maior não será dada a elas a fim de evitar que o presente ensaio teórico perca seu foco. 
A idéia segundo a qual a administração deve ser, devido a sua própria natureza, uma atividade moralmente "neutra", ou seja, uma atividade onde não se deve decidir sobre questões morais, mas somente sobre questões factuais, foi amplamente difundida no pensamento administrativo ocidental por inúmeros autores dentre os quais, curiosamente, se destaca Herbert Simon (1979), reconhecido como “[ ...] um dos pais da ciência administrativa moderna [ ...]" (Chanlat, 1999, p. 76). A despeito de ter abertamente reconhecido a indissociabilidade entre "ética" e "fato" na prática da tomada de decisão administrativa, Simon (1979) contraditoriamente propõe, ao elaborar sua teoria da tomada de decisão gerencial, que o comportamento administrativo deve se resumir a um problema puramente factual.

Segundo Simon (1979), uma decisão administrativa qualquer só pode ser corretamente conduzida a partir de uma avaliação estritamente factual dos seus elementos propositivos, avaliação essa que se torna impossível, segundo o autor, quando há nela a presença de qualquer moralidade. Isso porque, para Simon (1979, p. 48), “[ ...] não existe nenhuma maneira de demonstrar, empírica ou racionalmente, a correção das proposições éticas". Então, "[ ...] qualquer expressão que contenha um elemento ético, intermediário ou final, não pode ser descrita como correta ou incorreta [ ...]" (Simon, 1979, p. 52). Desse modo, a escolha de uma ação administrativa qualquer é, para Simon (1979), puramente uma questão de fato. Nas palavras do próprio autor,

constitui uma questão puramente factual saber se as medidas que ele [ o administrador] toma a fim de alcançar seus objetivos são medidas apropriadas. Saber se o fim em si mesmo é correto ou incorreto não constitui uma questão de fato exceto até o ponto em que o fim em causa acha-se jungido, por um a fim de, a outros fins (Simon, 1979, p. 51).

Para que as decisões administrativas possam ser corretamente desenvolvidas, Simon (1979) prescreve, então, que seus elementos éticos sejam de algum modo isolados dos seus elementos factuais pelo agente decisor. Isso implica que o agente decisor abandone o uso de qualquer valor moral nas suas escolhas, valendo-se apenas dos valores factuais para conduzi-las. Assim, explica o autor, "na medida em que essas decisões forem consideradas corretas, podem ser transformadas em proposições factuais. Seu elemento ético deve ser eliminado [ portanto] antes de se Ihe aplicar os termos verdadeira e falsa" (Simon, 1979 , p. 261). Desse modo,

é sempre possível avaliar as decisões nesse sentido relativo, podendo-se determinar, por exemplo, se elas são corretas à luz dos objetivos a que visam. [...] Falando num sentido estrito, não é a decisão em si que é avaliada, mas a relação puramente factual que é estabelecida entre a decisão e seus fins (Simon, 1979, p. 51).

Percebe-se, então, que, além de isolar, de forma arbitrária e contraditória, ética e fato nas decisões administrativas, Simon (1979) deixa de desenvolver e aprofundar qualquer reflexão sobre como tais decisões poderiam ser tomadas, avaliadas ou corrigidas moralmente. Embora reconheça a indissociabilidade entre os elementos factuais e os elementos éticos existentes na tomada de decisão administrativa concreta, Simon (1979) opta por separá-los ao prescrever sua teoria da decisão. O faz privilegiando os primeiros em detrimento dos segundos e, ao sustentar que as decisões devem ser tomadas exclusivamente com base em critérios factuais, abre espaço para ações administrativas moralmente indiferentes.

Uma vez sendo os valores morais abandonados pelo agente decisor que passa a avaliar os possíveis rumos de suas ações exclusivamente a partir dos valores factuais, todos os aspectos morais que continuam presentes na sua realidade decisória passam despercebidos para ele, ou seja, permanecem sem qualquer importância ou significado no que se refere às suas escolhas. Em outras palavras, as opções de conduta perdem todo seu peso moral aos olhos do agente decisor. Se o papel do administrador resume-se apenas a tomar, avaliar e corrigir as decisões estritamente sob o ponto de vista factual, cria-se um risco eminente de que decisões potencialmente antiéticas, porém “corretas" à luz de uma avaliação factual, sejam tomadas pelos administradores à margem de sua própria responsabilidade. Afinal, "se as instituições e arranjos sociais não têm significância moral, então o indivíduo não tem responsabilidade moral para com eles; um sistema de, digamos, leis, punições, governo, distribuição de riqueza, é apenas moralmente tão bom como qualquer outro" (Dewey \& Tufts, 2008, p. 341).

A partir do que foi exposto, pode-se dizer que as propostas de Simon (1979) sobre como deveria ser orientado o comportamento administrativo, embora muitas vezes entrem em contradição com suas análises sobre como esse comportamento realmente procede no dia-a-dia das organizações, acabaram por reforçar o entendimento de que a gestão deve ser uma atividade inerte a qualquer moralidade e que, por 
isso, deve procurar seu desenvolvimento exclusivamente no universo da "técnica"8. Nesse sentido, esclarece Chanlat (1999, p. 49),

a lógica da técnica parte da idéia de que o mundo humano é um conjunto de processos objetiváveis que se procura conhecer e controlar. Aproxima-se deles como se fossem independentes e facilmente manipuláveis. Utiliza intensamente o cálculo a fim de medir os resultados obtidos. O resultado que se espera é o de fazer recuar a "irracionalidade" do mundo social.

Por isso, reforça Chanlat (1999), Simon “[ ...] não hesitou em escrever que a gestão científica não precisa ter uma filosofia diferente da pesquisa operacional" (p. 38), assim como também "[ ...] não hesitou em escrever que não havia lugar para afirmações éticas em uma disciplina como a administração" (p. 76).

Já na década de 1950, pouco mais de dez anos após a primeira publicação de Comportamento Administrativo, Philip Selznick tece uma dura porém pertinente crítica à visão tecnicista de tomada de decisão administrativa ao discorrer sobre o "refúgio na tecnologia" (p. 63) em seu consagrado livro $A$ Liderança na Administração (1971).

Quando o administrador se refugia na tecnologia, explica o autor, ele se ocupa demasiadamente com questões operacionais, normalmente ligadas à busca pela eficiência organizacional, deixando de refletir sobre as próprias finalidades e propósitos das suas decisões. Nas palavras de Selznick (1971, p. 63), “tal posição é marcada por uma concentração de meios e métodos. As finalidades da ação são tidas como certas, encaradas como dados essencialmente aproblemáticos da estrutura da organização e da tomada de decisões". Então, continua o autor, "a retirada para a tecnologia ocorre sempre que um grupo foge a seus compromissos reais, tentando diminuir suas responsabilidades, retirando-se para trás de uma cortina de isolamento tecnológico, afastando-se de situações que geram ansiedade" (Selznick, 1971, p. 67).

Certamente, a mais evidente manifestação da retirada para a tecnologia é a própria fuga da responsabilidade moral, por parte dos administradores, de terem que avaliar moralmente (e não apenas tecnicamente) suas decisões e ações. Como explica Selznick (1971), este problema torna-se ainda mais intenso com o aumento da divisão vertical do trabalho entre planejadores e executores dentro das organizações, divisão esta que, ainda de acordo com o autor, ajuda a aprofundar a perigosa separação artificial entre fins e meios de gestão. Assim, continua Selznick (1971), questões morais de alta relevância são reduzidas a meros problemas técnicos dentro da organização ao mesmo tempo em que as questões técnicas ligadas aos meios e métodos operacionais de trabalho ganham importância primária aos olhos dos agentes decisores em detrimento da sua carga moral. Como consequência, tem-se uma prática administrativa moralmente alheia, porém tecnicamente legitimada, aos moldes daquela proposta por Herbert Simon (1979).

Em suma, o entendimento de Simon (1979) sobre como deveria ser conduzida a tomada de decisão gerencial foi fundamental para edificar a idéia de que a Administração “[...] se vale de métodos e instrumentos racionais para alcance de objetivos, independente de quaisquer juízos de valor ou colocações éticas" (Vidal, 2004, p. 109). Isso não significa que Simon (1979) desejasse que assim fosse. Esse autor se mostrou bastante consciente sobre os riscos de uma inadvertida separação entre ética e fato na condução da ação administrativa. Em suas palavras,

[ ...] considerar como neutra a própria atividade administrativa constitui uma abstração permitida dentro de amplos limites mas que, se levada a extremos, termina por ignorar valores humanos de suma importância. Esses valores podem abranger a remuneração e as condições de trabalho (aqui usados num sentido amplo) dos membros do grupo [ ...] (Simon, 1979, p. 193).

Assim, "o ritmo de trabalho dos empregados não pode ser considerado como um elemento neutro, pois poderíamos ser levados a concluir que sua aceleração seria sempre desejável" (Simon, 1979, p. 193). Do mesmo modo, continua o autor, "as políticas salariais, de promoção, e assim por diante, precisam ser consideradas não apenas como aliciantes e com vistas à eficiência dos resultados, mas também do ponto de vista da justiça distributiva para os membros do grupo" (Simon, 1979, p. 194). Prova inconteste de que Simon (1979, p. 193) esteve perfeitamente ciente das limitações da sua própria concepção parcial de comportamento administrativo é encontrada na declaração de que "outros critérios de natureza ética [também] devem ser aplicados ao problema da avaliação" das opções de conduta gerencial, além daqueles factuais. Todavia, esse é o ponto máximo ao qual chega Simon (1979) no sentido de considerar a natureza inegavelmente moral do comportamento administrativo em suas prescrições. 


\section{O Império da Racionalidade Instrumental: como a Crítica à Falta de Moralidade na Administração se Perde em Si Mesma}

Herbert Simon (1979) é um autêntico representante da ortodoxia do pensamento administrativo ocidental, pensamento esse que, por sua vez, é positivista, cético e operacionalista em sua mais íntima natureza (Procópio, 2008; Freeman, 2002; Bronzo \& Garcia, 2000; Chanlat, 1999; Aktouf, 1996; Eastman \& Bailey, 1994). Nesse sentido, não surpreende muito a revelação de que esse autor deliberadamente procurou ignorar a moralidade reconhecidamente presente no dia-a-dia gerencial ao prescrever como deveriam ser conduzidas as decisões administrativas, destacando apenas seus aspectos factuais.

Todavia, há autores críticos, dentre os quais se destaca Alberto Guerreiro Ramos (1989), que, partindo da premissa de que a Administração ocidental "evoluiu" na direção da exacerbação da racionalidade instrumental, da intensificação técnica de suas atividades e da desumanização do indivíduo que compõe as organizações, chegam à mesma conclusão sobre a eminente indiferença moral do agente decisor.

Segundo Guerreiro Ramos (1989), a sociedade moderna se caracteriza por uma "transvariação" racional. Há nela uma tendência para que todas as relações sociais sejam orientadas cada vez mais pela razão instrumental ou formal - oriunda do contexto específico das relações modernas de mercado e que é representada pelo cálculo utilitário de consequências - em detrimento da razão substantiva - oriunda das sociedades pré-industriais e que pode ser “[ ...] entendida como força ativa na psique humana que habilita o indivíduo a distinguir entre o bem e o mal, entre o conhecimento falso e o verdadeiro e, assim, ordenar sua vida pessoal e social" (Ramos, 1989, pp. 02-03). Segundo o autor, na sociedade moderna não apenas as relações econômicas de produção e de consumo se tornaram puramente instrumentais como também há uma forte tendência para que outras relações humanas também se instrumentalizem, mesmo aquelas que historicamente nunca tiveram uma vocação mercantil, como as relações familiares ${ }^{9}$.

Para Ramos (1989), a exacerbação da racionalidade instrumental na sociedade moderna centrada no mercado implica o esvaziamento da faculdade crítica do indivíduo em função da imposição extrínseca de uma forma de conduta mecanomórfica, cegamente pautada no consumismo e na acumulação material, que, ao final, se torna cronicamente compulsiva. Desse modo, argumenta Ramos (1989, p. 111), “[ ...] o ambiente social, como um todo, tornou-se, ele próprio, um ambiente mecanomórfico e, pela interiorização de suas normas e exigências, o indivíduo é induzido a se transformar, a si mesmo, num sistema mecanomórfico". O autor detalha seus argumentos ao diferenciar "comportamento" de "ação" e ao discorrer sobre a "síndrome comportamentalista".

O comportamento é uma forma de conduta que se baseia na racionalidade funcional ou na estimativa utilitária das consequências [ ...] Sua categoria mais importante é a conveniência. Em consequência, o comportamento é desprovido de conteúdo ético de validade geral. É um tipo de conduta mecanomórfica, ditada por imperativos exteriores [...] inclui-se, completamente, num mundo determinado apenas por causas eficientes. Em contraposição, a ação é própria de um agente que delibera sobre coisas porque está consciente de suas finalidades intrínsecas. Pelo reconhecimento dessas finalidades, a ação constitui uma forma ética de conduta (Ramos, 1989, pp. 50-51).

Guerreiro Ramos (1989) associa o comportamento ao uso da racionalidade instrumental e a ação ao uso da racionalidade substantiva e explica que a síndrome comportamentalista é exatamente a consequência da sobreposição da ação pelo comportamento, ou seja, da sobreposição da racionalidade substantiva pela racionalidade instrumental. Para o autor, "a síndrome comportamentalista, isto é, a ofuscação do senso pessoal de critérios adequados de modo geral à conduta humana, tornou-se uma característica básica das sociedades industriais contemporâneas" (Ramos, 1989, p. 52). Nessas sociedades ocorre, então, segundo Ramos (1989), uma crescente "desumanização" da ação na medida em que o comportamento das pessoas rumo ao consumo e à acumulação material se assemelha cada vez mais ao "comportamento" irrefletido das máquinas rumo à exaurição dos recursos naturais do planeta. Esse argumento é corroborado por Prestes Motta (2001, p. 100) que, ao entender, assim como Ramos (1989), que não pode haver moralidade no comportamento mecanomórfico ou compulsivo das pessoas, afirma que "a hegemonia da razão instrumental pressupõe a desvalorização do pensamento ético e da ação afetiva".

Dentro da organização formal ou burocrática, explica Guerreiro Ramos (1989), o administrador ou agente decisor se comporta do mesmo modo, a saber, age como uma peça em um maquinário no qual sua capacidade de avaliar moralmente suas próprias ações, ou seja, sua racionalidade substantiva, é substituída por um modo de comportamento racional-instrumental totalmente alienado e formalista. Por 
excelência, a organização formal é, para Ramos (1989), o espaço da tecnicização e da transformação do homem em um ser calculista. Nela, argumenta o autor, não há espaço para o indivíduo buscar nenhuma forma de auto-realização, independentemente do conteúdo dessa auto-realização, cabendo a ele apenas se conformar aos ditames da produtividade ou da eficiência, impostos externamente. Não obstante, ainda de acordo com Ramos (1989, p. 30), nela também não há espaço para nenhuma forma de ação ética já que, "no momento em que o ser humano é reduzido a uma criatura que calcula, é para ele impossível distinguir entre vício e virtude". Desse modo, Guerreiro Ramos (1989, p. 135) “[ ...] reconhece que, por sua própria natureza, o comportamento administrativo constitui atividade humana submetida a compulsões operacionais" e que tentar integrar o livre exercício da razão às exigências operacionais da organização formal só é possível ideologicamente.

Fortemente inspirado nas idéias de Guerreiro Ramos (1989), Maurício Serva (1997) também entende que a racionalidade instrumental - que, segundo ele, prevalece como lógica subjacente às decisões e ações administrativas na maior parte das organizações produtivas que atuam em um contexto competitivo de mercado - é pobre em julgamentos ético-valorativos. Para esse autor, o ambiente de trabalho nessas organizações é "[ ...] liberado das premissas ético-valorativas [ ...]" (Serva, 1997, p. 19). Por isso, continua ele, dentro dessas organizações há instrumentalização excessiva do ser humano, abusos de poder e impossibilidade de auto-realização; enquanto fora delas há poluição, degradação da qualidade de vida e desperdício dos recursos naturais do planeta.

A despeito desses malefícios, cuja veracidade está hoje acima de qualquer dúvida (exceto, talvez, pela completa impossibilidade de auto-realização), a questão é que Serva (1997), assim como Ramos (1989), vê o indivíduo que age e decide nas organizações formais ou burocráticas como seres moralmente vazios. Assumindo que as ações desses indivíduos são governadas pela racionalidade instrumental e assumindo que a racionalidade instrumental é aética, Serva (1997) reforça o posicionamento crítico de Ramos (1989), posicionamento segundo o qual o comportamento administrativo implica sérios danos ao indivíduo, à sociedade e ao meio ambiente justamente por não ser conduzido a partir de critérios morais, mas apenas a partir de critérios factuais. Com efeito, ao buscar definir e comparar os conceitos de racionalidade instrumental e racionalidade substantiva, Serva (1997, p. 22) opõe “julgamento ético deliberação baseada em juízos de valor (bom, mau, verdadeiro, falso, certo, errado etc.) [...]" e “maximização dos recursos - busca da eficiência e da eficácia máximas, sem questionamento ético, no tratamento de recursos disponíveis, quer sejam humanos, materiais, financeiros, técnicos, energéticos ou ainda, tempo", entendendo o primeiro como elemento constitutivo da racionalidade substantiva e o segundo como elemento constitutivo da racionalidade instrumental.

Apoiando-se também em Prestes Motta, além de Guerreiro Ramos, Maurício Serva (1992, p. 32) sintetiza esta perspectiva crítica afirmando que a "razão baseada no cálculo utilitário de consequências dos atos humanos [ ...]" impregna tais atos "[ ...] de um pensamento que conduz a um agir onde todos os meios são subordinados a determinados fins, relacionados à eficiência e à eficácia, eticamente inquestionados". Assim, continua o autor,

tal concepção da racionalidade, identificada com o produtivismo, desvaloriza o pensamento ético e a ação afetiva [ ...] bem como a intuição: cria e impõe uma 'nova' realidade ao ser humano, pretende um mundo totalmente tecnológico, o que para alguns quer dizer "racionalizado" (Serva, 1992, p. 32).

Em um trabalho mais recente, Fábio Vizeu (2009) reforça a idéia de que o comportamento gerencial é eminentemente um comportamento mecanizado e eticamente esvaziado. Ao discorrer sobre a racionalidade administrativa, aí entendida como racionalidade instrumental, o autor afirma que

este tipo de racionalidade desconsidera critérios normativos (normas e diretrizes da vida social, tais como a questão dos direitos e deveres em uma dada sociedade) e critérios éticos, aspectos estes que existem apenas no universo de significados criados pelos seres humanos (ou seja, são critérios não-válidos no universo das coisas e dos seres não humanos) [...] Assim, sob a prerrogativa da racionalidade instrumental, a sociedade atual não é caracterizada por sujeitos-humanos, mas por papéis e por funções, que são expressos em termos tais como "contribuinte", "paciente", "funcionário", “consumidor", etc. (Vizeu, 2009, p. 08).

Embora Guerreiro Ramos (1989) esteja correto ao afirmar que “[ ...] as organizações formais não constituem o cenário apropriado para [ ...] a auto-realização das pessoas" (p. 83), não ao menos para toda e qualquer forma de auto-realização, e que "as finalidades da vida humana são diversas e só umas poucas, dentre elas, pertencem, essencialmente, à esfera das organizações econômicas formais" (p. 125), sua concepção mecanicista de razão instrumental, compartilhada por Motta (2001), Serva (1997, 1992) e Vizeu 
(2009), exclui por completo a possibilidade de existência de qualquer avaliação moral por parte dos indivíduos que agem e decidem dentro das organizações, e é precisamente aí que tal análise crítica apresenta suas limitações.

A ação racional-instrumental é entendida pelos críticos aqui citados como uma ação fria e mecânica, como se os indivíduos que as executam fossem simplesmente autômatos, incapazes de sentir, interpretar e reagir reflexivamente sobre o que fazem; ou, ao contrário, é entendida como uma ação totalmente compulsiva e igualmente irrefletida. Porém, até para agir de modo aparentemente mecânico ou compulsivo rumo à maximização de utilidades é preciso que o agente social esteja sendo moralmente orientado; caso contrário, sua ação não poderia ser entendida, propriamente, como uma ação humana significativa (Procópio, 2006; Chanlat, 1996; Aktouf, 1996). Na verdade, o que escapa à análise crítica ora exposta é a percepção de que por trás de ações humanas aparentemente mecanomórficas e compulsivas, como aquelas supostamente praticadas pelos burocratas e tecnocratas nas organizações formais, há todo um sistema estruturado de valores éticos em funcionamento, algo que nem de longe seria possível caso os atores organizacionais realmente agissem do modo mecânico ou compulsivo imaginado pelos críticos ${ }^{10}$. Essa constatação se torna bastante evidente na discussão de Robert Merton (1973) sobre "estrutura burocrática e personalidade".

Certamente, Merton pode ser considerado um grande crítico da burocracia e das suas disfunções (Etzioni, 1976). Todavia, muito embora a análise crítica de Merton (1973) esteja disposta no sentido de demonstrar que, em caso de extrema burocratização da organização formal os burocratas se tornam agentes adaptativamente limitados, cegamente disciplinados, insensíveis às necessidades dos usuários do seu serviço e sem grande domínio intelectual do conteúdo e do propósito do seu próprio trabalho, esse autor também reconhece que a ação do burocrata não está completamente livre de uma orientação moral. Ao contrário, a ação do burocrata, para que seja realmente eficiente, depende de uma eficaz normatização moral e afetiva do seu comportamento dentro da organização. De acordo com Merton (1973, pp. 61-62),

[ ...] a estrutura burocrática exerce pressão constante sobre o funcionário para que seja "metódico", prudente e disciplinado [...] A disciplina apenas poderá ser eficiente se os padrões ideais [de comportamento] forem apoiados por fortes sentimentos, que resultem na devoção para com os deveres, um sentido aguçado da limitação da autoridade própria e da competência e desempenho metódico das atividades rotineiras. A eficiência da estrutura social depende, em última análise, de que as atitudes apropriadas e sentimentos se incorporem nos participantes do grupo.

Ademais, tal como argumenta Merton (1973), a burocracia é uma forma de organização conservadora na qual a "segurança vocacional" e a estabilidade do quadro funcional, ambas necessárias para garantir a prestação dos serviços com o mínimo de interferência externa possível, são importantes. Assim, a fim de garantir a proteção do serviço prestado e, além disso, a própria proteção do grupo dos burocratas, a estrutura burocrática cria um sentido de pertença e de identidade grupal marcado pela solidariedade corporativa e pela afetividade recíproca entre seus membros (Merton, 1973). Com efeito, "[ ...] os funcionários burocráticos identificam-se afetivamente com seu modo de vida" (Merton, 1973, p. 65). A obediência às regras e normas burocráticas se torna o pivô da conduta dos agentes e, “portanto, o comportamento que contraria estas normas formalizadas torna-se objeto de desaprovação, carregada de emoção", mesmo que este novo comportamento traga mais eficácia e eficiência à prestação do serviço em questão.

Daí segue que o "bom" burocrata é um executivo metódico e devoto às regras e procedimentos instituídos acima de qualquer outra coisa. Ele se orgulha de conhecer (mesmo que apenas formalmente e não funcionalmente) as regras e de sempre agir rigorosamente de acordo elas, compartilhando esse orgulho com os demais burocratas. Segundo Merton (1973), essa é a essência da "virtude burocrática".

Evidentemente, essa virtude burocrática faz sentido diante dos valores morais compartilhados dentro do próprio grupo dos burocratas (especialmente o valor da obediência às regras em primeiro lugar e o valor corporativista da proteção do grupo). Por outro lado, analisando a questão sob o ponto de vista do usuário do serviço burocrático, por exemplo, nota-se que talvez o burocrata esteja realizando um péssimo trabalho. Segundo Merton (1973), isso pode acontecer sempre que a adesão dos burocratas às regras internas fizer com que eles se esqueçam de que elas estão ali apenas para servir como meio regulatório para a prestação de um serviço final em conformidade com as necessidades de um usuário externo. Assim, quando a conformidade com as regras e procedimentos burocráticos toma proporções extremas, o burocrata se torna insensível aos problemas do usuário e, por isso mesmo, se "[...] torna incapaz de ajudar muitos de seus clientes" (Merton, 1973, p. 63). 
De qualquer modo, fica evidente aqui que é justamente a alta fidelidade dos agentes da organização aos valores morais burocráticos, e não uma suposta mecanização desses agentes, que faz com que eles, ao julgarem como "boa" ou "correta" suas condutas - por estarem elas em perfeita conformidade com as regras e procedimentos instituídos internamente - se transformem em indivíduos capazes de cometer as mais descabidas ações. Assim, como demonstrou Merton (1973), por trás do comportamento burocrático aparentemente mecânico, compulsivo e moralmente apático, há valores, sentimentos e interesses que não são de natureza técnica ou procedimental, mas sim, são de natureza eminentemente moral. Dito de outro modo, Merton (1973) demonstra que se o burocrata é um agente adaptativamente limitado, cegamente disciplinado, insensível às necessidades dos usuários do seu serviço e sem grande domínio intelectual do conteúdo e do propósito do seu próprio trabalho, isso ocorre justamente em função da sua forte fidelidade ao ethos burocrático e não em função de uma suposta mecanização do seu "ser".

Buscando apoio na Antropologia, Chanlat (1996) argumenta que o ser humano é um ser ativo e reflexivo. Para esse autor, imaginar que o ser humano pode ser exclusivamente guiado por coerção, instinto ou condicionamento é um erro já superado no campo do comportamento organizacional.

Em todo sistema social, o ser humano dispõe de uma autonomia relativa. Marcado pelos seus desejos, suas aspirações e suas possibilidades, ele dispõe de um grau de liberdade, sabe o que pode atingir e que preço estará disposto a pagar para consegui-lo no plano social (Chanlat, 1996, p. 29).

Nesse mesmo sentido, Aktouf (1996, p. 240), também se apoiando em idéias advindas do campo da Antropologia, afirma que

[...] os seres humanos não são assemelháveis a "organismos": eles obedecem a razões, a sentimentos e a determinadas escolhas e não a causas, salvo quando são constrangidos, heterodeterminados ou alienados, casos em que não é mais de sujeitos que se fala, mas de seres objetivados, coisificados (Aktouf, 1996, p. 240).

Essa concepção de ser humano, evidentemente mais realista do que aquela do "homem-máquina" que Guerreiro Ramos (1989) acredita estar se tornando hegemônica dentro das organizações formais e na própria sociedade contemporânea de modo geral, implica que sempre haverá espaço para a moralidade nas decisões e ações humanas, exceto, certamente, em casos de extrema deterioração das condições físicas, psíquicas, econômicas e/ou sociais de vida como de fato ocorreu, por exemplo, nos primeiros momentos da revolução industrial na Inglaterra segundo relato de diferentes autores como Karl Polanyi (2000), Leo Huberman (1986) e Harry Braverman (1987).

Em uma sociedade industrial "amadurecida" - na qual o poder econômico que os proprietários dos meios de produção exercem sobre aqueles que detêm a força de trabalho, embora continue existindo, já enfrentou historicamente diversas formas de resistência que vão desde a sindicalização da força de trabalho até a intervenção legal do Estado, e onde o próprio desenvolvimento histórico dessas duas forças antagônicas (capital e trabalho) já conseguiu forjar as instituições, costumes e hábitos dos diversos agentes sociais - seria arriscado não reconhecer a presença da moralidade na ação das pessoas. Por isso, se as ações que os indivíduos realizam nas organizações acarretam danos, a explicação para esse fenômeno gerencial deve ser procurada na própria estrutura moral das suas decisões e não em uma fictícia mecanização do agente decisor.

Em uma análise que, até certo ponto, lembra aquela empreendida por Guerreiro Ramos (1989), Eça de Almeida (1989) tenta demonstrar que a suposta amoralidade da Administração moderna se sustenta sobre a amoralidade que supostamente caracteriza a própria sociedade moderna, a sociedade “científicotecnológica". Como explica a autora, nessa sociedade dominada pela "tecnociência", embora haja abundância material, as relações sociais se encontram esvaziadas de valores morais. Em suas palavras, na sociedade científico-tecnológica “[ ...] desaparece completamente o senso dos valores, que nada mais são do que as noções em torno das quais o homem organiza o mundo e cria cultura, vivendo e constantemente emitindo juízos de valor" (Eça de Almeida, 1989, p. 47). A “[ ...] tecnociência é antiética, pois, onde não se pressupõe nem o ser, nem o sentido, onde reina unicamente a potência do possível, não existe mais lugar para os valores" (Eça de Almeida, 1989, p. 49). Mais precisamente, ainda segundo a autora, a "tecnociência" é niilista na medida em que não é ética e nem axiológica, "[ ...] é diferente da ética e está fora da ética [ ...]" (Eça de Almeida, 1989, p. 49).

É necessário concordar com os teóricos críticos quando eles afirmam que "as [ mesmas] técnicas modernas de administração e divisão do trabalho [que] tornaram inquestionavelmente mais produtiva a vida econômica [ ...] produziram, ao mesmo tempo, uma forma de se pensar e comportar absolutamente 
destrutiva e opressiva" (Motta, 2001, p. 102). Todavia, frente aos argumentos aqui apresentados faz-se também necessário admitir que isso não se deveu à "crise", eliminação ou mitigação do senso moral das pessoas que tomam decisões nas organizações, mas, ao contrário, à adoção, por parte delas, de critérios morais, provavelmente de natureza produtivista, que valorizam esse tipo de conduta destrutiva.

Por certo, "a sociedade moderna inclui em sua reprodução um conjunto de elementos e relações técnicas; vale dizer, um sistema técnico que implica a utilização técnica do homem" (Motta, 2001, p. 102). Todavia, a razão pela qual a atividade administrativa está se transformando em algo tão danoso ao ser humano, ao meio-ambiente e à própria sociedade não é de natureza técnica, mas sim é de natureza fundamentalmente moral. Desse modo, a solução para esses problemas não deve partir de um questionamento técnico da Administração e das suas teorias, processos e métodos, mas sim, deve partir de um profundo e sistemático questionamento das suas bases morais. Nesse sentido, Omar Aktouf (1996, p. 230) está correto quando diz que se faz necessário empreender "[...] uma análise dos 'códigos éticos' dominantes no mundo industrializado e dos fundamentos de "uma empresa com face humana'" para que se possa, ao final, tentar incorporar novos valores à prática gerencial.

Infelizmente, essa lição está pouco evidente nas análises críticas ora apresentadas, assim como também não se faz presente no pensamento ortodoxo sobre gestão, discutido na seção anterior. Ao contrário do que prescrevem alguns autores ortodoxos, como Herbert Simon (1979), a tomada de decisão administrativa dificilmente poderá ser moralmente neutra, uma vez que frequentemente vai muito além de uma simples ação "técnica". Paralelamente, essa mesma idéia de "neutralidade" moral reaparece transvestida na noção de "racionalidade instrumental" utilizada pelos teóricos críticos cujos argumentos já foram apresentados.

Assim como as idéias ortodoxas de Simon (1979), as idéias críticas ora discutidas também endossam o entendimento de que a atividade administrativa é moralmente indiferente. Desse modo, seus autores não inovam nas suas conclusões, mas sim apenas no seu método (crítico) de investigação e argumentação. Enquanto Simon (1979) se vale da idéia positivista de "neutralidade", os críticos se valem da idéia de indiferença ética presente na sua noção de racionalidade instrumental. Ambos sustentam que a tomada de decisão administrativa, por ser mecânica ou compulsiva, é moralmente vazia. Nesse sentido específico, a análise empreendida pelos críticos sobre a "perda" histórica de moralidade sofrida pela gestão leva ao mesmo ponto alcançado por aqueles autores ortodoxos para os quais a gestão deve ser, pela sua própria natureza, exclusivamente técnica e indiferente às questões morais. A despeito das inúmeras e profundas diferenças que existem entre essas duas perspectivas acadêmicas (ortodoxa e crítica), o fato é que, seguindo qualquer um desses dois caminhos chega-se ao mesmo ponto, a saber, à constatação de que haveria uma ruptura entre moralidade e materialidade na conduta administrativa, ruptura a partir da qual os valores morais e os valores factuais se tornariam excludentes para efeito de tomada de decisão.

É possível perceber, frente ao que foi discutido logo na primeira seção do presente ensaio teórico, que "ética" e "fato" fazem parte da mesma realidade complexa na qual decide e age o administrador. Além disso, verifica-se que a possibilidade de separação entre valores éticos e valores factuais no que diz respeito à orientação do comportamento administrativo é uma possibilidade que inexiste até mesmo para aqueles autores positivistas como Herbert Simon (1979). Agora, resta ainda verificar se o que vale para o comportamento administrativo dentro das organizações vale também para o comportamento mais amplo das pessoas na sociedade, especialmente numa "sociedade centrada no mercado" ou numa "sociedade científico-tecnológica".

A esse respeito, é possível sustentar que se hoje as pessoas estão se comportando de modo menos responsáveis com elas próprias, com a comunidade ou com o planeta, se estão se comportando de modo cada vez mais conveniente, imediatista, oportunista ou parasitário, isso não se deve ao fato delas estarem se transformando em animais irracionais ou em máquinas desgovernadas, nem mesmo se deve ao fato delas estarem sendo super-socializadas a ponto de se tornarem compulsivas e de perderem sua capacidade subjetiva de julgamento e discernimento moral por completo, mas sim, se deve ao fato de estarem agindo segundo valores morais que aprovam e estimulam esse tipo de conduta, valores esses que, embora sejam realmente adquiridos do meio social em que vivem, não são automaticamente reproduzidos em suas ações sem o mínimo de reflexão subjetiva. Portanto, são esses valores que devem ser questionados em uma crítica social de caráter histórico - cujo intuito seja descobrir como e porque eles vieram a existir, à quais interesses eles serviram e à quais interesses eles servem, quem se beneficiou e quem se beneficia hoje com eles, quem se prejudica e porque - e não uma suposta subtração da 
capacidade de julgar, decidir e agir moralmente que todo ser humano maduro apresenta, salvo em condições extremas e específicas.

\section{Considerações Finais}

A decisão administrativa concreta possui dimensões factuais e morais inexoráveis e irredutíveis entre si, embora a percepção das primeiras sempre condicione a percepção das segundas quando se trata da avaliação das opções de conduta, exceto em casos de total compulsão ou coerção do agente decisor. Ao contrário do que afirmam os autores que entendem a tomada de decisão administrativa como uma operação lógico-empírica ou racional-instrumental e nada mais, o presente ensaio teórico demonstrou, a partir de idéias de autores para os quais o comportamento administrativo vai além disso (Etzioni, 1988; Dewey, 1964; Selznick, 1971; Merton, 1973), que tal atividade é essencialmente moral. Dito de outro modo, foi teoricamente demonstrado aqui que não há e que não pode haver na prática administrativa decisões e ações humanas puramente racional-instrumentais ou formais que estejam desligadas de um sentido moral, exceto em casos extremos e específicos. Com efeito, ignorar isso implica assumir que os agentes decisores não são pessoas, mas sim máquinas, como fazem Guerreiro Ramos (1989) e os demais autores críticos que o seguem ao compartilharem a mesma concepção simplista de racionalidade instrumental, e como também o fazem os autores ortodoxos como Simon (1979) ao prescreverem que a tomada de decisão gerencial deve ser moralmente neutra. Por conseguinte, implica também assumir que os agentes decisores não são capazes de pensar, compreender, refletir, analisar, sentir e reagir significativamente à sua realidade. Não são capazes de justificar suas decisões e ações, nem mesmo são capazes de aprender com elas. Não são capazes de criar códigos e valores referenciais de conduta e, em última instância, não são capazes de criar instituições, cultura e história.

Embora a moralidade administrativa, que se manifesta nas escolhas e ações práticas e cotidianas dos agentes decisores nas organizações, possa de fato não estar sintonizada com aquilo que outros agentes esperam de uma "boa" gestão, nem por isso tal moralidade deixa de existir. Mais especificamente, os valores éticos ali presentes, embora possam não ser efetivamente capazes de promover a emancipação humana, o bem-estar social e a conservação ambiental, nem por isso deixam de orientar moralmente o comportamento real dos administradores.

A esse respeito, o presente ensaio teórico constatou falhas tanto no pensamento de autores ortodoxos como Herbert Simon (1979) quanto no pensamento de autores críticos como Alberto Guerreiro Ramos (1989). Enquanto a falha dos pensadores ortodoxos foi encontrada na sua consciente e deliberada recusa em querer lidar com a realidade moral que eles mesmos reconhecem existir por trás das decisões e ações administrativas aparentemente factuais, a falha dos críticos foi encontrada justamente na sua incapacidade de reconhecer tal realidade. Procedendo como os ortodoxos que projetam o comportamento administrativo como algo eticamente indiferente uma vez que entendem que ele deve ser guiado exclusivamente pela racionalidade instrumental, os críticos perdem, então, uma ótima oportunidade de realizar uma análise efetivamente crítica daquilo que realmente direciona a máquina mortífera da Administração, hipoteticamente, valores morais ligados ao produtivismo e à eficiência material das organizações acima de qualquer outra coisa. A falha dos críticos não está, então, no reconhecimento dos danos causados pela atividade administrativa, mas sim, está no mau entendimento da origem de tais danos. Com efeito, é a legitimação moral da ação administrativa, e não sua mera conformidade técnica, que dá a ela o poder de ser tão destrutiva. Assim, antes de colaborarem com o efetivo questionamento das práticas administrativas acertadamente danosas, esses críticos acabam por ajudar a camuflar, em uníssono com a idéia tecnicista de neutralidade moral dos pensadores ortodoxos, seus valores éticos orientadores, afastando, devido a sua própria incapacidade de vê-los, a possibilidade de qualquer intervenção consequente sobre o comportamento administrativo e seus males. Embora tenha sido criada com a melhor das intenções, a fim de sensibilizar a sociedade sobre os problemas da modernidade, a visão crítica do homem máquina parece mais com uma ficção científica do que com uma real descrição das causas desses problemas.

O aprimoramento técnico do trabalho e da gestão nas organizações, embora seja um fenômeno inconteste, não elimina a capacidade de julgamento ético dos indivíduos. Ao contrário, os altos níveis de tecnicização existentes na sociedade atual, corretamente apontados pelos autores críticos aqui citados, só puderam ser atingidos com o apoio de valores éticos específicos, particularmente presentes no campo da Administração e legitimados dentro e fora deste campo, valores esses que possibilitam que as pessoas 
encontrem justificação moral em ações baseadas no cálculo, na técnica e na norma formal, acima de qualquer outra coisa.

Em uma sociedade capitalista liberal, expressões populares como "ser uma máquina de fazer dinheiro" podem não apenas ter um sentido positivo para a maior parte das pessoas que precisam pagar pelo seu conforto e pelo seu bem-estar como também podem ajudar a revelar a orientação moral que rege a atividade empreendedora. Do mesmo modo, o popular ranking do "funcionário do mês" não serve apenas para cultivar um espírito competitivo e produtivo de curto prazo, especialmente na mente dos empregados mais jovens, mas também se torna motivo para busca e ostentação de um tipo de comportamento moralmente desejável dentro das empresas. Em suma, ao tentar agir como uma “máquina de fazer dinheiro" ou como o "funcionário do mês" o agente social, longe de estar desempenhando um papel coisificado e moralmente inerte dentro da sociedade e da organização, está, por outro lado, justamente buscando sentido moral em sua conduta. Mais do que isso, tal agente pode inclusive estar em busca de auto-realização, mesmo que seja em um sentido estrito, em conformidade com aquilo que prega uma sociedade centrada no mercado. Sua conduta pode estar sendo orientada por valores fortemente presentes e consagrados na cultura capitalista liberal como, por exemplo, o sucesso profissional, a acumulação material ou a competitividade. O indivíduo, então, projeta, deseja, cobiça, racionaliza e age, inclusive afetivamente, na direção aprovada por esses valores, acreditando intimamente que "essa é a coisa certa a fazer", por mais mesquinha, imediatista, conveniente, oportunista, ingênua ou parasitária que sua ação possa se mostrar para outro indivíduo que possui outros valores morais.

As decisões administrativas, por mais operacionais que sejam, sempre envolvem intenções e projetos de ação que se relacionam com a busca por uma "boa" gestão. Dificilmente um administrador que esteja realmente convencido de que está fazendo uma "boa" gestão será capaz de reconhecer que suas ações, visivelmente corretas sob o ponto de vista moral da Administração, são incorretas aos olhos de outros agentes sociais que compartilham outra perspectiva moral diferente daquela que existe nesse campo. Com efeito, isso pode ser um forte amplificador dos conflitos que frequentemente eclodem entre gestores e ambientalistas, sindicalistas e políticos. Quanto mais intenso for o compromisso do agente com os valores éticos presentes no campo da Administração, mais incapaz tal agente será de observar, a cada momento, as implicações morais de suas ações sob a perspectiva de outros valores éticos extrínsecos.

Não coube, no presente ensaio, uma discussão sistemática sobre o conteúdo dos valores morais que orientam a "boa" tomada de decisão administrativa. Nas ocasiões em que tais valores foram nominados a intenção foi apenas a de facilitar e ilustrar a argumentação a partir do uso de exemplos. Não obstante, para que tal discussão pudesse ser realizada com o mínimo de rigor científico, seria necessário primeiro especificar, com a maior precisão possível, que tipo de administração estaria sendo analisada (pública, privada, do terceiro setor) e em que contexto essa atividade administrativa estaria se desenvolvendo (tempo, local, condições sociais, políticas e econômicas) ${ }^{11}$. Por ora coube apenas demonstrar que a atividade administrativa é moralmente orientada e que dificilmente poderá ser compreendida, em sua completude, sem que sua dimensão moral seja considerada. Por conseguinte, uma "boa" decisão administrativa não é aquela que apenas guarda coerência ou proporcionalidade factual entre seus elementos empíricos, mas é, acima disso, aquela que é moralmente vista como "aprovada" por certo grupo de indivíduos.

Por certo, como analisam Chanlat (1999) e Aktouf (1996), hoje, mais do que nunca, faz-se necessário (re)introduzir uma série de questões éticas no mundo prático da administração, caso não se deseje que mais estragos humanos, sociais e ambientais aconteçam. Todavia, dizer que a atividade administrativa é desonesta, obscura e (socialmente, psicologicamente e ambientalmente) irresponsável não equivale simplesmente a dizer que tal atividade toma corpo sem qualquer consideração ética por parte de quem a realiza, a menos que se esteja arbitrariamente associando "ética" a honestidade, transparência e responsabilidade social como inadvertidamente fazem muitos autores que procuram discutir esse tema na Administração. Nesse mesmo sentido, entende-se aqui que o discurso que versa sobre a "indiferença", "crise" ou "esvaziamento" moral da conduta administrativa, difundido não apenas no senso comum, mas também na academia, além de ser demasiadamente impreciso por não revelar o ponto de vista moral a partir do qual o comportamento administrativo é avaliado, também acaba por desestimular uma verdadeira análise crítica e uma possível intervenção sobre a ação concreta dos gestores, simplesmente por não ser capaz de reconhecer que nela já há alguma forma de orientação moral. Então, uma vez que as decisões e ações administrativas são tanto orientadas por valores éticos quanto por valores factuais, não faz o menor sentido falar que a conduta administrativa é moralmente "vazia" e que precisa, por isso, ser eticamente 
preenchida. Do mesmo modo, também não faz sentido algum dizer que precisa haver um "reencontro" entre gestão e moral, técnica e ética ou ética e fato na tomada de decisão administrativa. Ao contrário, o que precisa ser urgentemente feito é um esforço no sentido de se reconhecer que embora as decisões administrativas tomadas pelos agentes decisores no interior das organizações possam de fato trazer consequências desastrosas, ainda assim elas gozam de embasamento e legitimidade morais. Isso, por sua vez, certamente torna a tarefa de contornar e/ou evitar tais consequências muito mais difícil do que a execução de qualquer intervenção "técnica". Para que a realização desse esforço seja possível, todavia, muita coisa ainda precisa mudar dentro dos pressupostos teóricos tanto dos pensadores críticos quanto dos pensadores ortodoxos da Administração. Até o simples reconhecimento de que as decisões e ações administrativas são eminentemente orientadas por valores morais pode ser algo muito desafiador “[ ...] especialmente numa área como a Administração, historicamente acusada de comportamentos pouco éticos, guiados exclusivamente pela racionalidade instrumental" (Sobral, 2010, p. 01).

Finalmente, evidencia-se no presente ensaio teórico que o impreciso, porém difundido, discurso sobre a "crise de ética" na Administração poderia se tornar muito mais útil em termos de crítica e eventual renovação do campo se a noção fictícia de vazio moral fosse substituída pela noção mais realista de conflito moral. Desse modo seria mais fácil reconhecer que a gestão contemporânea não passou a ser alvo de frequentes críticas (tanto externas quanto internas ao campo da Administração) por sofrer de "falta de ética", mas sim pelo fato de suas perspectivas éticas terem entrado em choque com outras perspectivas éticas existentes em outros grupos ou instituições cada vez mais influentes na vida social, econômica e política das pessoas. Assim, por exemplo, as "boas" decisões administrativas tomadas por um produtor agrícola que se orienta, por exemplo, pelo valor da "produtividade econômica" podem ser avaliadas como "ruins" por ambientalistas que as julgam, por exemplo, frente ao valor da "conservação ambiental" do mesmo modo como as "boas" decisões administrativas tomadas por um industrial que se orienta, por exemplo, pelo mesmo valor da "produtividade econômica" podem ser avaliadas como "ruins" por sindicalistas que as julgam, por exemplo, frente ao valor do "bem-estar do trabalhador". Em nenhum desses dois exemplos simplórios e meramente ilustrativos pode-se presumir que há uma lacuna entre um mudo ético, aquele do ambientalista ou do sindicalista, e um mundo não ético, o mundo do tomador de decisão gerencial. Ao contrário, ambos os casos tratam justamente do conflito que há entre diferentes moralidades.

Não obstante, nada pode impedir que os agentes decisores vivam "dilemas" morais provocados pela presença de dois ou mais valores éticos que competem entre si pela orientação de uma mesma ação. Todo campo de ação que se encontra minimamente instituído na sociedade, como o campo da Administração, tende a ser dominado por alguns poucos valores éticos hegemônicos que o caracteriza e o diferencia dos demais campos. Todavia, isso não significa que esse campo é hermético, nem que tais valores são os únicos que aí existem, nem mesmo que eles serão sempre os únicos a serem utilizados a todo e qualquer momento e em toda e qualquer situação vivida pelos agentes decisores. Afinal, o administrador se forma como um ator social moralmente competente não apenas dentro do campo da Administração de onde absorve seus valores específicos, mas também dentro de muitos outros campos pelos quais passa no decorrer do seu desenvolvimento moral. Isso significa que nem sempre o administrador será capaz de deixar "da porta para trás" seu "eu" ao entrar na organização para trabalhar e tomar decisões. Assim, certas situações nas quais o administrador se vê obrigado a decidir podem fazer com que ele traga para seu julgamento moral valores éticos oriundos de outros campos nos quais ele também participa como membro na sociedade como, por exemplo, o valor da "cidadania", da "equidade", da "solidariedade" ou do "bem-estar social". Como relatam James Waters e Frederick Bird (1987), dilemas morais dessa natureza podem surgir, por exemplo, quando o administrador se vê agindo no sentido do aumento da eficiência produtiva de uma fábrica a partir da depreciação da qualidade final do produto produzido ou a partir da diminuição das condições de segurança e bem-estar dos trabalhadores, ou ainda quando o administrador se vê agindo no sentido da maximização dos lucros a partir da utilização de matéria prima de baixa qualidade que pode comprometer a saúde e o bem-estar do usuário final do produto.

Certamente, as questões aqui relatadas nunca se esgotam em simples conflitos entre diferentes alternativas factuais de ação. Ao contrário, trata-se de conflitos entre diferentes perspectivas que definem o que é uma "boa" administração e em quais valores essa "boa" administração deve estar pautada: economia de recursos ou qualidade final do produto, eficiência produtiva ou bem estar dos trabalhadores, lucratividade ou preservação ambiental, etc.. Como bem observa Aktouf (1996, p. 18), decisões gerenciais voltadas para a redução de gastos e consequente aumento de rentabilidade podem ser avaliadas e adotadas como "boas" decisões administrativas, mesmo quando factualmente aumentam os riscos 
humanos. Segundo o autor, acidentes fatais ocorridos em operações de serviços de transporte tanto na Europa quanto nos Estados Unidos no final da década de 1980

originaram questões muito claras [ sobre as] políticas de rentabilidade adotadas [ pelas empresas operadoras], que, baixando os efetivos de pessoal e reduzindo os controles, contribuem para o aumento dos riscos. Entretanto, esta política é considerada geralmente como "boa administração": racionalizar, "enxugar" e reduzir ao máximo (Aktouf, 1996, p. 18)

É em razão da busca por essa "boa administração", então, que muitas vezes os agentes decisores deixam de observar dados e fatos empíricos que obviamente podem colocar muitos outros em situações perigosas, mesmo quando sua intenção não é causar-lhes mal algum. Entretanto, é importante frisar que o campo da Administração, como qualquer outro campo minimamente institucionalizado, não é indiferente à presença de outros valores morais além daqueles que se encontram nele referendados pelos hábitos e costumes vigentes. Por isso, sempre que optar por conduzir suas ações a partir de valores éticos estranhos ou contrários aqueles que dominam o campo da Administração, o indivíduo sempre estará sujeito a sanções ou retaliações por parte dos outros agentes que compõem esse campo.

Essas discussões revelam como é complexa a questão da tomada de decisão administrativa e o quanto ela vai além dos fatos e dados empíricos. Revelam, também, que há pela frente um longo, porém promissor, caminho rumo a novas formas de compreensão do comportamento administrativo, o caminho da investigação dos seus valores morais orientadores.

\section{Notas}

1- Todavia, os autores que fazem acusações dessa natureza parecem ignorar uma das mais importantes obras de Max Weber, A ética protestante e o espírito do capitalismo (2002), obra na qual o autor procura demonstrar que a busca pelo lucro, muito longe de ser algo não-ético, é, ao contrário, algo moralmente aceito e valorizado especialmente dentro do grupo dos agentes econômicos empreendedores cuja religião é Protestante.

2- Exemplos desses escândalos são relatados com detalhes no vídeo-documentário The Corporation de Abbott, Achbar e Bakan (2003).

3- No presente ensaio teórico, os termos "ética" e "moral" são utilizados como sinônimos, de maneira intercambiável. De acordo com Yves de La Taille (2006, p. 25), "tal sinonímia é perfeitamente aceitável: se temos dois vocábulos é porque herdamos um do latim (moral) e outro do grego (ética) [ ...]".

4- De acordo com John Dewey (2008a), sob o ponto de vista estritamente lógico não há diferença entre esses dois valores no que diz respeito a sua função de mediar, para o indivíduo que decide, as duas dimensões da mesma realidade decisória complexa, a dimensão factual e a dimensão moral, muito embora eles estejam hierarquicamente sobrepostos no que diz respeito ao nível de importância heurística que possuem. Assim como ocorre no mundo inanimado dos fatos, "concepções e princípios que servem para medir ou avaliar a conduta e as relações morais são logicamente do mesmo tipo, e devem ser assim tratadas na prática social" (Dewey, 2008a, p. 217).

5- "Nosso interesse neste estudo está focado nessa visão de valores humanos como critérios, ao invés da visão alternativa de valores como qualidades inerentes aos objetos" (Schwartz \& Bilsky, 1987, p. 551).

6- Como fica aqui evidente, com base na menção ao princípio administrativo da "autoridade e responsabilidade" e aos sub-processos da administração ("previsão, organização, comando, coordenação e controle"), a obra clássica de Henri Fayol, Administração Industrial e Gera/ (1990), pode servir como importante referência para a sistematização dessas discussões.

7- Com efeito, em um sistema capitalista o dinheiro assume um importante papel como escala de medida geral aplicável à tomada de decisão administrativa uma vez que todos os valores factuais podem, em última instância, ser comparados diretamente a partir dele (Weber, 1994; Simon, 1979). Como explicita Max Weber (1994, p. 53) "do ponto de vista puramente técnico o dinheiro é o meio de cálculo econômico 'mais perfeito', isto é, o meio formalmente mais racional de orientação da ação econômica". Simon (1979, p. 181), por sua vez, simplifica e dá concretude a esse entendimento ao afirmar que na Administração "[ ...] o dinheiro proporciona um denominador comum para mensuração da produção e da renda, permitindo que ambas sejam comparadas diretamente". 
8- E não se trata de um reforço irrelevante, graças a enorme penetração e difusão que o texto de Simon (1979) atingiu tanto dentro quanto fora do campo da Administração.

9- Nas palavras do autor, “[ ...] graças à natureza da sociedade global contemporânea, a família está [ ...] se transformando num fenômeno de organização formal" (Ramos, 1989, p. 124). Não obstante, "mesmo a subjetividade privada do indivíduo caiu prisioneira da racionalidade instrumental" (Ramos, 1989, p. 13).

10- É importante notar que esse sistema de valores éticos não se confunde com o sistema ideológico corretamente observado por Guerreiro Ramos (1989) em sua discussão sobre a "política cognitiva" (p. 86 em diante). Apenas a título de esclarecimento, pode-se dizer que enquanto a "política cognitiva" tem por finalidade conformar ideologicamente o agente organizacional à sua condição de recurso mecanizado e coisificado, oferecendo a ele um falso sentido existencial onde de fato não existia nenhum (Ramos, 1989), os valores éticos estão presentes nas decisões e ações de indivíduos que verdadeiramente agem de modo significativo, sentindo e refletindo sobre a realidade organizacional na qual atuam.

11- Fica desde já lançada a sugestão para pesquisas futuras.

\section{Referências}

Abbott, J., Achbar, M., \& Bakan, J. (2003). The Corporation. Big Picture Media Corporation. [ vídeodocumentário, DVD-ROM].

Aktouf, Omar. (1996). A administração entre a tradição e a renovação. São Paulo: Atlas.

Bartlett, D. (2003). Management and Business Ethics: a critique and integration of ethical decision-making models. British journal of Management, 14, 223-235.

Berger, P., \& Luckmann, T. (1985). A Construção social da realidade. Petrópolis: Vozes.

Blackburn, S. (1997). Dicionário Oxford de Filosofia. Rio de Janeiro: Jorge Zahar Editor.

Bourdieu, P. (2001). Razóes práticas (3a ed.). Campinas: Papirus.

Braverman, H. (1987). Trabalho e capital monopolista: a degradação do trabalho no século XX (3a ed.). Rio de Janeiro: Editora Guanabara.

Bronzo, M., \& Garcia, F. (2000, junho). As bases epistemológicas do pensamento administrativo convencional e a crítica à teoria das organizações. Anais do Eneo, Curitiba, PR, Brasil, 1.

Chanlat, J. (1996). Por uma antropologia da condição humana nas organizações. In J. Chanlat (Coord.). $O$ indivíduo na organização: dimensões esquecidas (Vol. 1, 3a ed., pp.21-45). São Paulo: Atlas.

Chanlat, J. (1999). Ciências Sociais e management. São Paulo: Atlas.

Coltro, A., \& Aparecido dos SANTOS, S. (1998, setembro). A busca da compreensão da racionalidade e da ética da ação administrativa na gestão de uma organização hospitalar pública. Anais do Enanpad, Foz do Iguaçu, PR, Brasil, 22.

Dewey, J. (1964). Teoria da vida moral. São Paulo: IBRASA.

Dewey, J. (2008a). Logic: the theory of inquiry (pp. 200-219, The Collected Works of John Dewey, The Latter Works 1925-1953, Vol. 12: 1938). Carbondale: Southern Illinois University Press.

Dewey, J. (2008b). Theory of valuation (The Collected Works of John Dewey, The Latter Works 1925-1953, Vol. 13: 1938-1939). Carbondale: Southern Illinois University Press.

Dewey, J. (n.d.). Human nature and conduct: an introduction to Social Psychology (The Modern Library books collection). Nova York: Random House.

Dewey, J., \& Tufts, J. (2008). Ethics (The Collected Works of John Dewey 1882-1953, The Latter Works $1925-$ 1953, Vol. 7: 1932). Carbondale: Southern Illinois University Press.

Eastman, W., \& Bailey, J. (1994). Examining the Origins of Management Theory: value divisions in the positivist program. Journal of Applied Behavioral Science, 30(3), 313-328. 
Administração e valores: em busca de novos caminhos para a compreensão do comportamento administrativo

Eça de Almeida, M. (1989). Tentativa de explicitação de uma Ética da não-potência na sociedade científicotecnológica. Reflexão - Instituto de Filosofia da PUCCAMP, 45, 47-50.

Enriquez, E. Os desafios éticos nas organizações modernas. RAE-Revista de Administração de Empresas, 37(2), 06-17.

Etzioni, A. (1976). Organizações modernas (5a ed.). São Paulo: Pioneira.

Etzioni, A. (1988). The moral dimension: toward a new economics. Nova York: The Free Press.

Fayol, H. (1990). Administração industrial e geral (10a ed.). São Paulo: Atlas.

Freeman, E. (2002). Toward a New Vision for Management Research. Journal of Management Inquiry, 11(2), 186-189.

Hayibor, S., \& Wasieleski, D. (2009). Effects of the use of the availability heuristics on ethical decisionmaking in organizations. Journal of Business Ethics, 84(1), 151-165.

Huberman, L. (1986). História da riqueza do homem (21a ed.). Rio de Janeiro: LTC.

La Taille, Y. (2006). Moral e Ética: dimensões intelectuais e afetivas. Porto Alegre: Artmed.

Merton, R. (1973). Estrutura burocrática e personalidade. In A. Etzioni (Org.). Organizações complexas: estudo das organizações em face aos problemas sociais (pp. 57-69). São Paulo: Atlas.

Motta, F. (2001). Teoria das organizações: evolução e crítica (2a ed.). São Paulo: Pioneira.

Perocca, M. (1997). Valores que norteiam o processo de tomada de decisão da enfermeira. Revista da Escola de Enfermagem da USP, 31(2), 206-218.

Polanyi, K. (2000). A grande transformação: as origens de nossa época (2a ed.). Rio de Janeiro: Elsevier.

Porto, J., \& Tamayo, A. (2007). Estrutura dos Valores Pessoais: a relação entre valores gerais e laborais. Psicologia: Teoria e Pesquisa, 23(1), 63-70.

Procópio, M. (2006, setembro). O Sentido Percebido pelo Ator: em Busca de uma Teoria da Ação mais Abrangente e Humana para a Compreensão das Organizações. Anais do Enanpad, Salvador, BA, Brasil, 30.

Procópio, M. (2008, setembro). Valores Factuais e Valores Éticos na Ciência Administrativa. Anais do Enanpad, Rio de Janeiro, RJ, Brasil, 32.

Provis, C. (2010). Virtuous decision making for business ethics. Journal of Business Ethics, 91, 03-16.

Ramos, G. (1989). A nova ciência das organizações (2a ed.). Rio de Janeiro: FGV.

Ravlin, E. (2003). Valores. In C. Cooper \& C. Argyris (Orgs.). Dicionário Enciclopédico de Administração (pp. 1401-1403). São Paulo: Atlas.

Schwartz, S., \& Bilsky, W. (1987). Toward a universal psychological structure of human values. journal of Personality and Social Psychology, 53(3), 550-562.

Selznick, P. (1971). A liderança na administração: uma interpretação sociológica. Rio de Janeiro: FGV.

Serva, M. (1992). O paradigma da complexidade e a análise organizacional. RAE-Revista de Administração de Empresas, 32(2), 26-35.

Serva, M. (1997). A racionalidade substantiva demonstrada na prática administrativa. RAE - Revista de Administração de Empresas, 37(2), 18-30.

Simon, H. (1979). Comportamento administrativo (3a ed.). Rio de Janeiro: FGV.

Sobral, F. (2010). Relação dinâmica entre confiança, competitividade e o processo de tomada de decisão ética em negociação. RAE - Eletrônica, 9(2).

Tamayo, A. (1998). Valores organizacionais: sua relação com satisfação no trabalho, cidadania organizacional e comprometimento afetivo. RAUSP - Revista de Administração, 33(3), 56-63.

Tamayo, A., \& Gondim, M. (1996). Escala de valores organizacionais. RAUSP - Revista de Administração, $31(2), 62-72$. 
Vidal, F. (2004). Para o acervo de raridades: uma discussão epistemológica no âmbito da ciência da administração. In R. Santos (Org.). A administração política como campo do conhecimento (pp. 106-118). São Paulo: Mandacaru.

Vizeu, F. (2009, setembro). Racionalidade Administrativa e Distorção Comunicativa nas Organizações Contemporâneas. Anais do Enanpad, Rio de Janeiro, RJ, Brasil, 33.

Waters, J., \& Bird, F. (1987). The moral dimension of organizational culture. Journal of Business Ethics, 6(1), 15-22.

Weber, M. (1994). Economia e sociedade (Vol. 1, 3a ed.). Brasília: UnB.

Weber, M. (2002). A ética protestante e o espírito do capitalismo. São Paulo: Martin Claret. 